\title{
13
}

\section{Media stars and neoliberal news agendas in Indigenous policymaking}

\author{
Kerry McCallum and Lisa Waller
}

\section{Introduction}

Our essay uses a media studies lens to examine the ascendancy of neoliberal policy agendas in Indigenous affairs. The Media and Indigenous Policy project ${ }^{1}$ has been investigating the dynamic interplay between news media and the complex, politically sensitive and uneven bureaucratic field of Indigenous affairs. A particular focus has been to investigate the news media's power to construct problems and suggest solutions in the Indigenous policy field. This essay draws on that research to argue that conservative news outlets have sponsored a narrow range of Indigenous voices to articulate and promote neoliberal policy agendas to government. We examine how The Australian newspaper, as the keystone media on Indigenous affairs, was integral to the rise of Noel Pearson as the singular influence on Indigenous affairs. In doing so, we acknowledge and pay tribute to the thinking of Jon Altman in the development of our ideas, and for his support throughout this project. Altman's public discussion

$1 \quad$ Australian News Media and Indigenous Policymaking 1988-2008 (DP0987457). 
of the 2007 Northern Territory Emergency Response made him one of the few Australian public intellectuals to think and act outside the dominant neoliberal discourse on Indigenous policy.

\section{Neoliberal agendas in Indigenous affairs policy}

The constructivist approach to policymaking (Colebatch 2002, Bacchi 2009) foregrounds the discursive battles that frame some issues as problems to be solved and enable some solutions to be heard more clearly than others. This approach problematises the dominant assumption that Indigenous affairs is 'intractable', 'wicked' or an area of 'policy failure', and helps explain sharp swings and occasional dramatic announcements such as the 2007 Northern Territory Emergency Response (NTER or Intervention). It reminds us that the policies that govern Indigenous peoples are rooted in the history of Australian colonisation and the complex processes of federalism. It tells us not to assume a direct effect of media content on policy, but rather see news media are part of the discursive environment in which problems are constructed and policy solutions are developed to address those problems.

Altman (2010) has documented the shift to a neoliberal agenda in Indigenous affairs policy by Labor and Coalition governments since the mid-1990s. We use the term neoliberalism, drawing on Altman, to mean the adoption of 'market-based technical solutions to complex, deeply entrenched and diverse development problems' (Altman 2010: 268). Despite the range of possible policy responses, and Aboriginal and Torres Strait Islander peoples' resilience and determination to represent the diversity of their opinion, a neoliberal perspective has come to dominate the Indigenous policy field. Federal governments have increasingly implemented social policy that has intervened in Indigenous Australians' lives with the explicit aim of exposure to the market. Interventionist policies such as welfare quarantining may appear to contradict neoliberalism's promise of free market individualism, but as Peters (2011) observes, neoliberalism emphasises the dominance of the individual over the state while simultaneously and selectively raising the social above the individual. In this way, neoliberalism can be offered as a rationale for coercive and interventionist policies, as well as for policies that promote free market activity. 


\section{Indigenous affairs reporting in Australia}

There is a widespread belief that the news media wield great influence in the Indigenous policy sphere (Manne 2011). Our project builds on a long line of research that finds that the content of news is, indeed, an important influence on policy. But we would argue that media influence is frequently subtle and deeply embedded in the relationships between influential players in the media and policy fields.

The Media and Indigenous Policy project mapped the reporting of Indigenous health in three Australian newspapers from 1988-2008. While not a comprehensive content analysis of all media coverage of all Indigenous news, our findings paint a stark picture of the content and quality of reporting, and provide a basis for our wider analysis. We conclude that Indigenous health was of limited and uneven interest to mainstream news media (see Fig. 13.1). Reporting followed a 'shallows and rapids' pattern, whereby Indigenous issues were most often ignored, but when they were reported, coverage was intense, sensationalist, and short-lived (Fleras \& Kunz 2001).

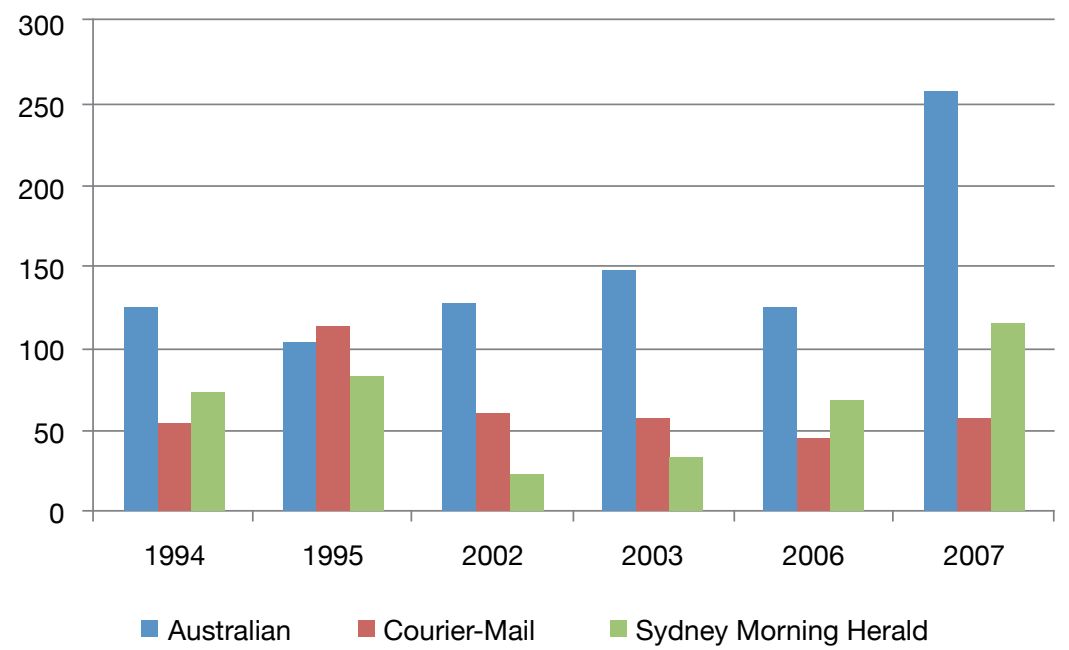

Fig. 13.1 Indigenous health reporting: Number of stories in The Australian, Sydney Morning Herald and Courier Mail, 1994-95, 2002-03, 2006-07

Source: Authors' research 
Social policy domains such as Indigenous health were represented as political issues, with federal parliamentary leaders given the overwhelmingly loudest voice in news coverage. Qualitative analysis identified that news stories about Indigenous issues are typically told through frames of crisis, failure of government policy and individual responsibility, whereby Indigenous people are blamed for their own plight (McCallum 2011, 2013).

\section{The Australian, Noel Pearson and Indigenous affairs}

Our research has shown that between 1988 and 2008 The Australian was the only newspaper to report substantially on Indigenous health. Our finding that The Australian set the news agenda on Indigenous affairs is not surprising. As the flagship of Rupert Murdoch's NewsCorp and Australia's only national daily broadsheet newspaper, The Australian is an influential organ of news; it is a 'campaigning', loss-making but politically significant newspaper (Cryle 2008, McCallum \& Reid 2012, McKnight 2012). We argue that The Australian is the keystone media source in the Australian Indigenous reporting landscape. Keystone media, according to Nielsen (2015), are defined not by their reach or ubiquity, but in terms of their systemic importance, their significance not for the majority of media users, but for the wider information environment they inhabit. The public servants, journalists and Indigenous policy advocates interviewed for our study contended that The Australian occupied the strongest position in the field of Indigenous reporting. The Australian had the biggest and most specialised reporting staff, the highest number of exclusives, devoted the most editorial space, committed resources both in Canberra and in remote Australia, and, most importantly, was the most closely listened to by opinion leaders, senior bureaucrats and political leaders. Its award-winning journalists bring substantial symbolic capital to the field (McCallum \& Waller 2013). The Australian's editors have deliberately and self-consciously made national discussion of Indigenous affairs a focal point (Brook 2012). Former editor Paul Kelly laid out The Australian's contribution to Indigenous affairs in a keynote address at a 2014 conference to mark its 50th anniversary: 
On Indigenous issues in recent decades the paper, I think, has taken some landmark positions. We have been very committed to moving away from what we feel was the commitment to progressive and unsuccessful policies in Indigenous affairs. We have worked with a number of Indigenous leaders in particular, Noel Pearson, to try to change the agenda and put a much greater emphasis on individual responsibility (Kelly 2014).

Participants in our study commented on the rise of conservative commentators during the Howard era as key players in policy debates, acknowledging in particular Noel Pearson's 'stunning success in engaging the eye of the mainstream'. Maddison (2009: xxxvi) however noted the contested ascendance of Noel Pearson among 'other Indigenous leaders'. Pearson is an Aboriginal Queenslander with deep cultural, political and economic capital (Curchin 2013). A senior Indigenous affairs bureaucrat told us:

And you know, he's incredibly well connected in government so every government wants a Pearson tick of approval. Every government actively seeks it out. They just can't help themselves because there isn't any other Indigenous leader with the same credit rating.

The Australian's political reporter Patricia Karvelas (2007) even went so far as to credit Pearson with convincing John Howard that 'his desire to activate the biggest social reform of his decade in power [the NTER] was right'. A policy insider noted his impact on government policy when he said:

So [Pearson's] notion about individual responsibility, that it's not all up to governments, is a really, really important one ... [then Prime Minister] Tony Abbott is one of his biggest fans. And Tony, to his credit, has done things very much as a result of Noel ... He has a very strong ideology.

We are interested in how certain individuals, like Pearson, come to occupy the intersection between news media and Indigenous policymaking by appearing to define the terms of public discourse and suggesting policy solutions. Waller (2010b) developed the concept of 'singular influence' to understand the power of the state and the media to consecrate a certain individual, such as Pearson, to promote their hegemonic, neoliberal rationalities, which are presented as so much common sense (Couldry 2010). We argue that The Australian newspaper aligned its reporting with the state's neoliberal policy 
agendas through its deployment of Noel Pearson as a regular commentator, anointed Indigenous leader and a singular influence on Indigenous affairs.

Pearson became an influential news source for The Australian during the Howard years. Our content analysis found that he was reported as a spokesperson on Indigenous health in The Australian twice as often as any other Indigenous person. More significantly, for a decade and a half, its editors gave Pearson a platform to present his views unmodified, through a series of invited columns. An analysis of 137 of these columns, published most often in the influential Weekend Australian between 2004 and 2011, revealed that Pearson used this platform to articulate his neoliberal policy agenda of individual responsibility, welfare reform, engagement with the mainstream economy, mobility, and home ownership.

In an invited column on 27 July 2004 for the 40th anniversary of The Australian, Pearson established the argument against what he and others, such as Peter Sutton (2009), have referred to as the 'liberal consensus':

The liberal consensus during The Australian's lifetime was that Aboriginal disadvantage was caused by the denial of self-determination and denial of rights and services, and by discrimination ...

The Australian, for all its faults, is the main national forum for this painful reassessment (Pearson 2004b).

Through his columns, Pearson set about systematically dismantling the liberal consensus. He idealised life prior to the 1967 referendum, criticised the move to legally enforce equal wages for Aboriginal workers, and blamed welfare rights for the current dependence among many Indigenous people on 'passive welfare'. While supporting land rights, Pearson strongly advocated private home ownership. He also promoted mobility - one of the currents of neoliberalism (Torres \& Carte 2014)-arguing that Indigenous people move away from community to attend school or to find work (Pearson 2004a). In a 2005 piece he asserted:

Indigenous social, educational and economic progress depends at least as much on increased geographic mobility and economic interaction with the national and global economies (Pearson 2005). 
He extolled the importance of engagement with the 'real economy', noting that 'Work for the dole is always better than sit-down money, but it should never become a permanent alternative to work in the real economy' (Pearson 2006b). As Altman (2013) points out, Pearson is often vague about the 'real economy', but suggests that people should move away from programs such as CDEP, (which he refers to as passive welfare despite its requirement to work), to engagement with market capitalism through employment in mining or tourism. Pearson has been consistent in his insistence on personal responsibility to cure the ills that keep many Indigenous Australians in the margins of society, advocating that: 'For most people, the road to self-reliance ascends the "staircase of opportunity"' (Pearson 2006c). In the tradition of key neoliberal thinkers such as Hayek and Friedman, he advocates private choice as the answer to economic and social problems:

The analogous sclerosis afflicting indigenous society is the pervasive absence of responsibility at the individual, family and community levels (Pearson 2006c).

In what might at first appear a contradictory stance, but in line with neoliberal thinking, Pearson has supported coercive, interventionist measures as necessary first steps toward breaking the dependency of Indigenous communities on government (Pearson 2006a). Despite his argument that their relationship with government was one of the biggest problems faced by Indigenous people, Pearson insisted the first step on the road to responsibility was 'the immediate need for government to intervene in those communities where the safety and protection of children and community members is an urgent priority' (Pearson 2006a). This view was reiterated in 2007 following the announcement of the NTER. In a series of articles where Pearson appeared to distance himself from this dramatic suite of policies, he nevertheless gave tacit support to measures such as welfare quarantining on the basis that at least the Howard government was acting on child sexual abuse (e.g. Pearson 2007a). Shortly after, Pearson commented as follows:

... I believe liberal and conservative insights and policies currently have more to contribute to indigenous uplift than some outdated conventional progressive thinking (Pearson 2007b). 


\section{Conclusion}

On 15 July 2014, at a dinner to celebrate the 50th anniversary of The Australian newspaper, Pearson came together with Rupert Murdoch and then Prime Minister Tony Abbott. In his speech to that dinner, Pearson (2014: 53) said: 'For those like me whose reform policies have been steadfastly supported by the paper's editorials, we have not been spared contrary views and criticism in news reporting and commentary. The dialectic of the national conversation plays out in the pages of The Australian'. We agree with Pearson's assessment that The Australian has committed significant resources to the reporting of Indigenous affairs, and its journalists have done much to raise awareness of the range of issues facing Indigenous Australians (Waller 2010a, 2013). We also agree that The Australian's framing of Indigenous affairs news was not identical to Pearson's, and Pearson's views were not always in accord with those of the governments he influenced, or The Australian's editorial line.

We do not, however, agree with Pearson's suggestion that The Australian fairly represented the diversity of views on Indigenous affairs. Our analysis leads us to conclude that Pearson, The Australian and federal government decision-makers were discursively aligned'a singular influence'. The Australian's sponsorship of Noel Pearson gave him an unprecedented univocalism and effectively blocked from view other ways of imagining Indigenous policy issues. We contend that The Australian's sponsorship of Pearson effectively narrowed the scope of debate on Indigenous affairs. This chapter has briefly outlined theoretical and empirical insights into the role of keystone news outlets like The Australian in promoting neoliberalism as the point of view of the dominant, which presents and imposes itself as a universal. In other words, neoliberalism has emerged as the hegemonic way of understanding the social world and the news media plays a key role in promoting neoliberal 'realities'. 


\section{References}

Altman JC (2010). What future for remote Indigenous Australia? Economic hybridity and the neoliberal turn. In Altman JC \& Hinkson M (eds), Culture crisis: anthropology and politics in Aboriginal Australia, UNSW Press, Sydney.

Altman JC (2013). Evidently: seeing through the smoke and mirrors of a black job hunt. Tracker 12 November.

Bacchi C (2009). Analysing policy: what's the problem represented to be? Pearson, Frenchs Forest.

Brook S (2012). Intellect and work ethic keep Mitchell in chair for 20 years. The Australian 4 June.

Colebatch HK (2002). Policy, 2nd edn, Open University Press, Maidenhead.

Couldry $N$ (2010). Why voice matters: culture and politics after neoliberalism, Sage, London.

Cryle D (2008). Murdoch's flagship: twenty-five years of The Australian newspaper, Melbourne University Press, Melbourne.

Curchin K (2013). Discursive representation and Pearson's quest for a radical centre. Australian Journal of Political Science 48(3):256-68.

Fleras A \& Kunz JL (2001). Media and minorities: representing diversity in a multicultural Canada, Thompson, Toronto.

Karvelas P (2007). Moved by Pearson's passion, Weekend Australian 23-24 June:1.

Kelly P (2014). Paul Kelly, keynote address to symposium marking 50 years of The Australian, video recording, Macquarie University, 7-8 July, Sydney. Retrieved from www.youtube.com/ watch? $\mathrm{v}=\mathrm{g} 9 \mathrm{EeVUSk} 7 \mathrm{CU}$.

Maddison S (2009). Black politics: inside the complexity of Aboriginal political culture, Allen \& Unwin, Sydney.

Manne R (2011). Bad news: Murdoch's Australian and the shaping of the nation. Quarterly Essay 43:1-119. 
McCallum K (2011). Journalism and Indigenous health policy. Australian Aboriginal Studies 2011(2):21-31.

McCallum K (2013). Distant and intimate conversations: media and Indigenous health policy in Australia. Critical Arts 27(3):324-44.

McCallum K \& Reid H (2012). Little children and big men: campaigning journalism and Indigenous policy. Australian Journalism Review 34(2):71-84.

McCallum K \& Waller L (2013). Media interventions in Indigenous policymaking. Media International Australia 149:139-49.

McKnight D (2012). Rupert Murdoch: an investigation of political power, Allen \& Unwin, Sydney.

Nielsen RK (2015). Introduction: the uncertain future of local journalism. In Nielsen R (ed.), Local journalism: the decline of newspapers and the rise of digital media, IB Taurus, London.

Pearson N (2004a). No danger of another stolen generation. The Australian 5 November.

Pearson N (2004b). Two stories of Indigenous affairs. The Australian 27 July.

Pearson N (2005). Reconciliation a building block. The Australian 19 April.

Pearson N (2006a). Big government hurts Aboriginal population. The Australian 26 June.

Pearson N (2006b). Join the real world. Weekend Australian 16-17 December.

Pearson N (2006c). Road to responsibility. Weekend Australian 30 September -1 October.

Pearson N (2007a). Politics aside, an end to the tears is our priority. The Australian 23 June.

Pearson N (2007b). Leftist policies pave kids' road to hell. The Australian 21-22 July. 
Pearson N (2014). A rightful place: race, recognition and a more complete Commonwealth. Quarterly Essay 55:53-4.

Peters M (2011). Neoliberalism and after? Education, social policy and crisis of Western capitalism, 2nd edn, Peter Lang, New York.

Sutton P (2009). The politics of suffering: Indigenous Australia and the end of the liberal consensus, Melbourne University Press, Melbourne.

Torres R \& Carte L (2014). Community participatory appraisal in migration research: connecting neoliberalism, rural restructuring and mobility. Transactions of the Institute of British Geographers 39(1):140-54.

Waller L (2010a). Indigenous research ethics: new modes of information gathering and storytelling in journalism. Australian Journalism Review 32(2):19-31.

Waller L (2010b). Singular influence: mapping the ascent of Daisy M. Bates in popular understanding and Indigenous policy. Australian Journal of Communication 37(2):1-14.

Waller L (2013). It comes with the territory: 'Remote' Indigenous reporting for mainstream Australia. Australian Journalism Monographs 14:5-38. 
This text is taken from Engaging Indigenous Economy: Debating diverse approaches, edited by Will Sanders, published 2016 by ANU Press, The Australian National University, Canberra, Australia. 